\title{
Copyright Protection for Mass-Produced, Commercial Products: A Review of the Developments Following Mazer v. Stein†
}

By holding that commercial use does not invalidate copyright registration, the Supreme Court in Mazer $v$. Stein ${ }^{1}$ ushered in a brave new world of copyright law, filled with costume jewelry, ${ }^{2}$ toy dolls, ${ }^{3}$ fabric designs, ${ }^{4}$ artificial flowers, ${ }^{5}$ and plastic Santa Clauses. ${ }^{6}$ The extension of copyright status to such mass-produced, two- and threedimensional objects ${ }^{7}$ has placed great stress on a system designed

$\uparrow$ Entered in the Nathan Burkan Memorial Competition.

1347 U.S. 201 (1954). The plaintiffs in Mazer had secured copyrights on statuettes of male and female dancing figures and subsequently used the statuettes as lamp bases. When the defendant marketed identical lamps, the plaintiffs sued for infringement of their copyrights. The defendant claimed that the intended and actual commercial use of the statuettes invalidated the copyright registration. The Court rejected this defense. Id. at 218.

2 See, e.g., Herbert Rosenthal Jewelry Co. v. Grossbardt, 428 F.2d 551 (2d Cir. 1970); Dan Kasoff, Inc. v. Novelty Jewelry Co., 309 F.2d 745 (2d Cir. 1962); Boucher v. Du Boyes, Inc., 258 F.2d 948 (2d Cir.), cert. denied, 357 U.S. 936 (1958); Trifari, Krussman \& Fishel, Inc. v. Charel Co., 134 F. Supp. 551 (S.D.N.Y. 1955).

3 See, e.g., Uneeda Doll Co. v. Goldfarb Novelty Co., 373 F.2d 851 (2d Cir.), cert. dismissed, 389 U.S. 801 (1967); Ideal Toy Corp. v. Fab-Lu Ltd., 860 F.2d 1021 (2d Cir. 1966); Ideal Toy Corp. v. Sayco Doll Corp., 302 F.2d 623 (2d Cir. 1962); Rushton v. Vitale, 218 F.2d 434 (2d Cir. 1955).

4 See, e.g., Concord Fabrics, Inc. v. Marcus Brothers Textile Corp., 409 F.2d 1315 (2d Cir. 1969); H.M. Kolbe Co. v. Armgus Textile Co., 315 F.2d 70 (2d Cir. 1963); Millworth Converting Corp. v. Slifka, 276 F.2d 443 (2d Cir. 1960); Peter Pan Fabrics, Inc. v. Martin Weiner Corp., 274 F.2d 487 (2d Cir. 1960).

5 See, e.g., Florabelle Flowers, Inc. v. Joseph Markovits, Inc., 296 F. Supp. 304 (S.D.N.Y. 1968); Gardenia Flowers, Inc. v. Joseph Markovits, Inc., 280 F. Supp. 776 (S.D.N.Y. 1968); Rico, Ltd. v. Hub Floral Mfg. Co., 206 F. Supp. 192 (S.D.N.Y. 1962); Prestige Floral Societe Anonyme v. California Artificial Flower Co., 201 F. Supp. 287 (S.D.N.Y. 1962).

6 Doran v. Sunset House Distrib. Corp., 197 F. Supp. 940 (S.D. Cal. 1961), aff'd, 304 F.2d 251 (9th Cir. 1962).

7 The term "mass-produced products" as used in this comment refers to items which do not fall within the normal concept of works of fine art, for example such items as toy dolls, fabric designs, artificial flowers, and plastic Santa Glauses. It is not intended to include mass-produced works of fine art. Although this distinction is not self-defining, the courts should not have great difficulty in administering the test. After all, before Mazer the courts denied copyright protection to two- and three-dimensional objects which did not qualify as works of fine art.

On the other hand, it should be remembered that commercial products and works of 
basically for literary works. ${ }^{8}$ Strict $^{9}$ notice requirements ${ }^{10}$ have been virtually ignored in order to avoid denying protection to some copyrighted articles. Thus, courts have approved notice located on the underside of an artificial flower leaf, ${ }^{11}$ the clasp of a necklace, ${ }^{12}$ and other places where close scrutiny is required to locate the inscription..$^{13}$ Moreover, even this obscure, nearly microscopic ${ }^{14}$ notice is unnecessary on fabric designs. Notice may be placed on the selvage of the cloth, which often winds up on the cutting room floor as the fabric is made into finished retail products. ${ }^{15}$ Consequently, anyone attempting to copy a dress design acts at his own peril, ${ }^{16}$ unless he can prove that notice could have been incorporated into the design without destroying its market value.17 Furthermore, some courts have sug-

fine art are not totally separate concepts. Therefore, many of the comments made about the former are also applicable to the latter. However, any detailed analysis of works of fine art is beyond the scope of this comment.

8 The first copyright statute, the Statute of Anne, 8 Anne, c. 19 (1710), covered only books. While insuring statutes over the next 250 years gradually added other forms of expression, the basic conceptual framework of the copyright law remained tied to the literary model. See generally B. KAPLAN, AN UNHURRIED VIEW of COPYRIGHT 1-37 (1967).

9 The notice provisions of the Act have been described as "do-or-die" requirements, KAPLAN, supra note 8 , at 81 , and the sine qua non of copyright protection, NiMarer, CopYRIGHTS \$ 82 , at 302 (1970) [hereinafter cited as NMIMER].

10 Publication of works without statutory notice or with inadequate notice normally destroys the right to secure copyright. 17 U.S.C. $\$ 8$ (1964); 37 C.F.R: $\$ 202.2(a)(2)$ (1971). The precise manner, form, and placement of notice are prescribed by statute. 17 U.S.C. $\S \S 10,19-20$ (1964). Only accidental omissions of these requirements are excused. 17 U.S.C. $\S 21$ (1964).

11 Prestige Floral Societe Anonyme v. California Artificial Flower Co., 201 F. Supp. 287, 291 (S.D.N.Y. 1962).

12 Trifari Krussman \& Fishel, Inc. v. Charel Co., 134 F. Supp. 551, 554 (S.D.N.Y. 1955).

13 See, e.g., Ted Arnold, Ltd. v. Silvercraft Co., 259 F. Supp. 733, 734 (S.D.N.Y. 1966) (stamped on the base of a brass striker between the bells on the top of an antique telephone); Scarves By Vera, Inc. v. United Merchants \& Mfrs., Inc., 173 F. Supp. 625, 628 (S.D.N.Y. 1959) (woven label sewn into sideseam immediately adjacent to bottom opening of garment).

14 Microscopic notice would be invalid. 37 C.F.R. § 202.2(b)(8) (1971).

15 See, e.g., H.M. Kolbe Co. v. Armgus Textile Co., 315 F.2d 70, 73 (2d Cir. 1963); Peter Pan Fabrics, Inc. v. Martin Weiner Corp., 274 F.2d 487, 490 (2d Cir. 1960).

16 Publication ... is considered to have occurred on sale of the printed goods to the dress manufacturers, and notice at that time is to be held constructive notice to all dress manufacturers, provided the notice was sufficient. In that event, a copier acts at his peril if he takes the design from a finished dress.

Peter Pan Fabrics, Inc. v. Dixon Textile Corp., 280 F.2d 800, 803 (2d Cir. 1960); accord, Loomskill, Inc. v. Slifka, 223 F. Supp. 845, 849 (S.D.N.Y. I963), aff'd, 330 F.2d 952 (2d Cir. 1964).

17 Peter Pan Fabrics, Inc. v. Martin Weiner Corp., 274 F.2d 487, 490 (2d Cir. 1960); Loomskill, Inc. v. Slifka, 223 F. Supp. 845, 849 (S.D.N.Y. 1963), aff'd, 330 F.2d 952 (2d Cir. 1964). 
gested that even that defense is not available to a willful infringer with actual notice. ${ }^{18}$

Despite these significant changes in the notice rules, the greatest impact of the Mazer decision has been in more substantive areasthe concept of originality, the test for infringement, and the distinction between ideas and expression. This comment will examine the substantive problems raised by Mazer, focusing particularly on the idea-expression distinction, which is central to the entire concept of copyright protection. This survey will then be used as a basis for reexamining the Mazer decision itself.

\section{Commercial Copyright and the Idea-Expression Distinction}

The idea-expression distinction is a basic tenet of copyright law. ${ }^{19}$ It marks the boundary line between the protected and the unprotected, between the elements of a copyrighted work which others may not copy and those elements which may be freely appropriated. Ideas have traditionally been placed in the unprotected category, ${ }^{20}$ because of the fear that

[t]o grant property status to a mere idea would permit withdrawing the idea from the stock of materials which would otherwise be open to other authors, thereby narrowing the field of thought open for development and exploitation. ${ }^{21}$

Expression, on the other hand, falls squarely within the ambit of the protected classification. Curiously, the justification for granting copyright status to expression is quite similar to the rationale for denying it to ideas. That is, expression must be protected in order to persuade authors to share their ideas and thereby "advance the public welfare." 22

Unfortunately, the idea-expression distinction defies exact definition. Over forty years ago, Judge Learned Hand tried to describe it in terms of a series of abstractions:

18 Uneeda Doll Co. v. Goldfarb Novelty Co., 373 F.2d 851, 854 (2d Cir.), cert. dismissed, 389 U.S. 801 (1967); Dan Kasoff, Inc. v. Novelty Jewelry Co., 309 F.2d 745, 746 (2d Cir. 1962); Prestige Floral Societe Anonyme v. California Artificial Flower Co., 201 F. Supp. 287, 291 (S.D.N.Y. 1962).

19 For early formulations of the idea-expression distinction, see Holmes v. Hurst, 174 U.S. 82, 86 (1898); Baker v. Selden, 101 U.S. 99, 102 (1879).

20 The unprotected status of ideas, at least those contained in some tangible medium of expression, does not seem to be constitutionally required. NIMMER § 8.4, at 22; KAPLAN, supra note 8 , at 64 .

21 NIMLMer § 143.11, at 621.

22 Mazer v. Stein, 347 U.S. 201, 219 (1954). 
Upon any work, and especially upon a play, a great number of patterns of increasing generality will fit equally well, as more and more of the incident is left out. The last may perhaps be no more than a general statement of what the play is about, and at times might only consist of its title; but there is a point in this series of abstractions where they are no longer protected, since otherwise the playwright could prevent the use of his "ideas" to which, apart from their expression, his property is never extended. ${ }^{23}$

Obviously Hand's formulation is not a definition at all, but rather a way of viewing the problem. Although everyone seems dissatisfied with such a hazy solution, attempts to articulate more concrete standards have largely failed. Chafee has suggested that copyright protection covers the pattern of the work, which, in the case of a play, includes "the sequence of events and the development of the interplay of the characters." ${ }^{24}$ Nimmer advocates a combination of the Hand and Chafee approaches. ${ }^{25}$ Others have urged reformulating the ideaexpression distinction in terms of a "spine-idea" test ${ }^{26}$ or a content analysis. ${ }^{27}$ However, none of the above concepts provides a precise definition of where to draw the line between ideas and expression; like the abstractions test, they remain means of approaching the problem, not an answer to it.

These definitional problems apparently led Judge Hand to abandon any attempt to find a unifying principle. Almost thirty years after enunciating his abstractions test, he remarked:

Obviously, no principle can be stated as to when an imitator has gone beyond copying the "idea," and has borrowed its "expression." Decisions must therefore inevitably be ad hoc. ${ }^{28}$

The complex task of separating ideas from expression becomes more complicated in the area of commercial copyright. First, the subject matter involved is usually a two- or three-dimensional object whose impact is quite different from that of a novel or play: more visual and immediate, appealing more to the aesthetic and less to the

23 Nichols v. Universal Pictures Corp., 45 F.2d 119, 121 (2d Cir. 1930), cert. denied, 282 U.S. 902 (1931).

24 Chafee, Reflections on the Law of Copyright: 1, 45 CoLUM. L. REv. 503, 513-14 (1945). 25 NIMMER § 143.11, at 623.

26 Libott, Round the Prickly Pear: The Idea-Expression Fallacy in a Mass Communications World, 16 ASCAP COPYRIGHT L. SYM. 30 (1968).

27 Sorensen \& Sorensen, Re-examining the Traditional Legal Test of Literary Similarity: A Proposal for Content Analysis, 37 CoRNerr L. Q. 638 (1952).

28 Peter Pan Fabrics, Inc. v. Martin Weiner Corp., 274 F.2d 487, 489 (2d Cir. 1960). 
intellectual sensibilities of the viewer. Since articles such as fabric designs, costume jewelry, and artificial flowers evoke a Gestalt response, they cannot easily be broken down into component parts like plot, theme, and character development and, thereby, analyzed in terms of a series of abstractions or a pattern test. As a result, the idea-expression distinction becomes "even more intangible." 29

These difficulties are compounded by a second factor-the absence of major substantive barriers to obtaining copyright registration. Unlike patent law, copyright law does not demand novelty or invention..$^{30}$ Nor must a copyrighted work possess a great degree of creativity. Although the Copyright Regulations state that a work of art "must embody some creative authorship in its delineation or form,"31 the courts have been quite unwilling to sit in judgment of artistic merit. ${ }^{32}$ As Justice Holmes stated:

It would be a dangerous undertaking for persons trained only to the law to constitute themselves final judges of the worth of pictoral illustrations outside of the narrowest and most obvious limits. At the one extreme, some works of genius would be sure to miss appreciation. Their very novelty would make them repulsive until the public had learned the new language in which their author spoke. It may be more than doubted, for instance, whether the etchings of Goya or the paintings of Manet would have been sure of protection when seen for the first time. At the other end, copyright would be denied to pictures which appealed to a public less educated than the judge. Yet, if they command the interest of any public, they have a commercial value-it would be bold to say that they have not an aesthetical and educational value-and the taste of any public is not to be treated with contempt. ${ }^{33}$

29 Id.

30 Mazer v. Stein, 347 U.S. 201, 218 (1954). Two courts have stated that a copyrighted work must possess some degree of novelty. Dan Kasoff, Inc. v. Novelty Jewelry Co., 309 F.2d 745, 746 (2d Cir. 1962); Rushton v. Vitale, 218 F.2d 434, 435 (2d Cir. 1955). However, in both cases the term "novelty" seems to have been used interchangeably with "originality" and use of the former term did not impose any requirements on copyright registration other than those already contained in the latter concept.

Similarly, the patent law standard of contribution to the prior art has been employed in one case, but only to support the conclusion that the copyrighted product possessed the requisite originality. Trifari, Krussman \& Fishel, Inc. v. Charel Co., 134 F. Supp. 551, 553 (S.D.N.Y. 1955).

3137 C.F.R. § 202.10(b) (1971).

32 Lack of creativity has been used to bar copyright protection only where the Register of Copyrights refused registration, Bailie v. Fisher, 258 F.2d 425 (D.C. Cir. 1958), or where the copyrighted work also failed to meet the originality requirement, Gardenia Flowers, Inc. v. Joseph Markovits, Inc., 280 F. Supp. 776 (S.D.N.Y. 1968).

33 Bleistein v. Donaldson Lithographing Co., 188 U.S. 239, 251-52 (1902). Much the 
The courts have also failed to make use of a Regulation ${ }^{34}$ disqualifying from copyright registration works whose sole intrinsic function is utility. Here, however, the inaction of the courts does not reflect judicial restraint. Rather, the Regulation itself has little applicability. There are no two-dimensional works and few three-dimensional objects whose design is absolutely dictated by utilitarian considerations. In essence, then, the initial burden of excluding commonplace matters in the public domain, such as ideas, from copyright status has been left solely to the originality requirement. Unfortunately, it does not perform this function very effectively.

The originality requirement is extremely minimal. Most courts ask only that the "artist" contribute something more than trivial to his work. ${ }^{35}$ Frequently, all that is required of the copyrighted work is that it not be an exact duplicate of another article. ${ }^{36}$ Thus, sufficient originality has been found in the reduction of an existing threedimensional design to two-dimensions, ${ }^{37}$ in the reduction in size a Rodin statue; ${ }^{38}$ in the printing of nineteenth century drawings of Beethoven, Brahms, and Bach on sweatshirts; ${ }^{39}$ and in the production of a three-dimensional plastic Santa Claus..0

The effect of these and numerous other decisions ${ }^{41}$ has been to grant copyright status to objects comprised mainly of material in the public domain. Furthermore, in many cases the attractiveness or commercial value of the copyrighted work, public domain elements included, depends on its incorporation into another product. Few of the numerous design cases in the Southern District of New York

same philosophy also seems to have pervaded the Mazer decision: "Individual perception of the beautiful is too varied a power to permit a narrow or rigid concept of art." 347 U.S. at 214.

3437 C.F.R. $\$ 202.10$ (c) (1971) provides in part:

If the sole intrinsic function of an article is its utility, the fact that the article is unique and attractively shaped will not qualify it as a work of art.

35 Alfred Bell \& Co. v. Catalda Fine Arts, 191 F.2d 99, 103 (2d Cir. 1951).

36 Tennessee Fabricating Co. v. Moultree Mfg. Co., 421 F.2d 279, 281 (5th Cir.), cert. denied, 398 U.S. 928 (1970).

37 Gardenia Flowers, Inc. v. Joseph Markovitz, Inc., 280 F. Supp. 776, 782 (S.D.N.Y. 1968).

38 Alva Studios, Inc. v. Winninger, 177 F. Supp. 265, 267 (S.D.N.Y. 1959).

39 Eagle-Freedman Roedelheim Co. v. Allison Mfg. Co., 204 F. Supp. 679, 681 (E.D. Pa. 1962).

40 Doran v. Sunset House Distrib. Corp., 197 F. Supp. 940, 944 (S.D. Cal. 1961), affd, 304 F.2d 251 (9th Cir. 1962).

41 See, e.g., Gelles-Widmer Co. v. Milton Bradley Co., 313 F.2d 143, 147 (7th Cir.), cert. denied, 373 U.S. 913 (1963) (arrangement of educational flash cards already in public domain); Rushton v. Vitale, 218 F.2d 434, 436 (2d Cir. 1955) (toy doll modeled after a live chimpanzee); Loomskill, Inc. v. Slifka, 223 F. Supp. 845 (S.D.N.Y. 1963), aff'd, 330 F.2d 952 (2d Cir. 1964) (minor variations in Audubon book drawing of birds); John Wolf Textiles, Inc. v. Andris Fabrics, Inc., 139 U.S.P.Q. 365, 367 (S.D.N.Y. 1962) (replica drawings of people from Cleopatra's era). 
would likely have arisen if the designs involved had been sold by themselves as works of art instead of incorporated into fabrics which could be made into dresses and other retail products. The courts are, therefore, forced to distinguish protected expression not only from public domain elements in a particular design, but also from the product into which that design is incorporated. As previously mentioned, the subject matter of most commercial copyrights makes drawing such fine distinctions exceedingly difficult.

Instead of facilitating this task, a third factor-the standard of infringement--exacerbates the problem. The normal test for infringement is "whether an average lay observer would recognize the alleged copy as having been appropriated from the copyrighted work." 42 Thus, despite the difficulty of distinguishing between ideas and expression in commercial copyright cases, the court is forced to formulate its judgment on the basis of an overall impression-precisely the level at which the public domain elements are most likely to predominate. Close examination to detect disparities is discouraged; ${ }^{43}$ expert testimony is viewed with distrust, if not hostility. ${ }^{44}$ In short, the test for infringement may deprive the court of the very tools it needs to handle the complicated idea-expression distinction.

Faced with such complex and bewildering problems, most courts have seemed to follow human instinct-they have simply ignored the questions raised by the idea-expression distinction. Frequently, the courts conclude their inquiry by pointing to evidence of actual copying. Such a resolution of infringement proceedings, however, is less than satisfactory. In terms of the idea-expression concept, evidence of actual copying is irrelevant if only ideas are appropriated. A careful judicial examination is still needed to determine specifically which elements of the copyrighted work may or may not be protected. With-

42 Ideal Toy Corp. v. Fab-Lu Ltd., 360 F.2d 1021, 1022 (2d Cir. 1966).

43 See, e.g., Peter Pan Fabrics, Inc. v. Martin Weiner Corp., 274 F.2d 487, 489 (2d Cir. 1960); Prestige Floral Societe Anonyme v. California Artificial Flower Co., 201 F. Supp. 287, 293 (S.D.N.Y. 1962).

44 The traditional hostility to expert testimony in copyright cases was expressed by Judge Learned Hand in Nichols v. Universal Pictures Corp., 45 F.2d 119, 123 (2d Cir. 1930), cert. denied, 282 U.S. 902 (1931):

We cannot approve the length of the record, which was due chiefly to the use of expert witnesses. Argument is argument whether in the box or at the bar, and its proper place is the last. The testimony of an expert upon such issues, especially his cross-examination, greatly extends the trial and contributes nothing which cannot be better heard after the evidence is all submitted. It ought not to be allowed at all; and while its admission is not a ground for reversal, it cumbers the case and tends to confusion, for the more the court is led into the intricacies of dramatic craftsmanship, the less likely it is to stand upon the firmer, if more naive, ground of its considered impressions upon its own perusal.

This attitude may have changed somewhat in recent years. See the use of expert testimony in Mattel, Inc. v. S. Rosenberg Co., 296 F. Supp. 1024, 1027 (S.D.N.Y. 1968). 
out such an investigation, reliance on actual copying will provide unwarranted protection for many items within the public domain. Two cases involving toy dolls illustrate this point.

In the first case, Remco Industries, Inc. v. Goldberger Doll Manufacturing Co., ${ }^{45}$ the plaintiff claimed that the defendant had infringed its copyright on dolls resembling the Beatles. The court found similarity and copying without discussing either concept. On this basis, it issued a preliminary injunction forbidding the defendant from manufacturing or selling "a doll approximately five inches tall, representing a male figure wearing a dark suit and exhibiting a 'mop' haircut associated with the musical group known as the Beatles."46

The problem with the decision is in attempting to define the original expression that is protected. Certainly the plaintiff could not claim the exclusive right to make dolls resembling the Beatles. The Beatles were in the public domain and any semi-accurate representation would, of necessity, have to involve a male figure with a "mop" haircut. Arguably the original expression came either in dressing a Beatle figure in a dark suit, or in making the doll five inches high, or both. But what if the defendant had put a different color suit on its doll? Or altered the height of the doll by a half inch?

Similar problems are raised by a second doll case, Hassenfeld Brothers, Inc. v. Mego Corp., ${ }^{47}$ in which the plaintiff held a copyright on a soldier doll called "GI Joe." After the plaintiff had spent over four million dollars in advertising and the product had sold seven million copies, ${ }^{48}$ the defendant attempted to market a considerably less expensive version called "Fighting Yank." Actual copying seemed obvious, since both dolls had an identically misplaced right thumbnail. Considering the average lay observer test satisfied, the court granted a preliminary injunction.

Again, specifying the original expression which justified the injunction is a difficult if not impossible task. In reaching its decision, the court pointed to three types of similarities: first, features of the head, torso, legs, arms, and hands, including the misplaced thumbnail; second, the fact that the dolls were sold with a variety of accessories and changes of clothing; and finally, the mechanical construction of both dolls, which allowed them to be posed in various attitudes. The defendant surely had the right to copy the mechanical construction, which was unpatented and not part of the registered copyright. Similarly, the defendant should not have been prohibited from either

45141 U.S.P.Q. 898 (E.D.N.Y. 1964).

$46 \mathrm{Id}$. at 899 .

47150 U.S.P.Q. 786 (S.D.N.Y. 1966).

48 Id. at $786-87$. 
selling dolls with accessories or dressing those dolls in standard Army uniforms and equipping them with standard guns and hand grenades. Thus, the plaintiff's original expression, if it subsisted at all, must have been in the dolls themselves. The court purported to find such expression and to find it infringed. Although differences existed in the face and head of the two dolls, "they are both faces which depict a well groomed young man with black hair with head and nasal features which are very similar." 49

Yet if copyright protection rests on the clean-cut appearance of the soldier, obvious problems arise. Must one who manufactures an American soldier doll with standard uniforms and weaponry also give that doll an unshaven appearance? More basically, is it even possible to change the facial expression of the dolls sufficiently to alter the overall similarity which is undoubtedly comprised of elements within the public domain - the human body, the soldier's uniform, and the military weapons? The fact that the defendant's doll is an obvious copy of the plaintiff's may explain the court's avoidance of these questions, but it can hardly serve as a justification.

Not all courts placing primary reliance on evidence of actual copying ignore these implications. In Sunset House Distributing Corp. $v$. Doran, ${ }^{50}$ the court examined two painted plastic bags which, when completely stuffed with crumpled newspaper, turned into threedimensional Santa Clauses. Characterizing the defendant's product as a "lazy copy," 51 the Ninth Circuit affirmed judgment for the plaintiff. Perhaps troubled by the possibility of giving the plaintiff a monopoly on all three-dimensional plastic Santa Clauses, it sought to clarify its decision:

The court below has not enjoined defendants from making a Santa Claus, a red and white plastic Santa Claus, or a Santa Claus with a slit in his back to permit him to be stuffed with newspapers. ${ }^{52}$

The result is doubletalk. The defendant's product had a different belt buckle than the plaintiff's; different material was used for the figure's face and the hood of its tunic. ${ }^{53}$ The only points of identity between the two products seem to be the very features the court said the defendant could appropriate-a three-dimensional figure of Santa

49 Id. at 788 .

50304 F.2d 251 (9th Cir. 1962), aff'g 197 F. Supp. 940 (S.D. Cal. 1961).

51 Id. at 252. The defendant had even copied plaintiff's instruction sheet.

52 Id. at 252.

53 197 F. Supp. at 940, 947-48. 
Claus, plastic material, and the slit in the back to permit the bag to be stuffed with newspapers. In short, the defendant could have copied the plaintiff's product if they had not been so "lazy" in doing so.

The obvious course of conduct for potential copyists, therefore, is not to be lazy. A knowledgeable entrepreneur can usually place the courts in a position in which they cannot ignore the problems raised by the idea-expression distinction. At least one New York firm of fabric converters, the Slifkas, seems to have pursued this strategy successfully. They were able to win three cases, despite admitting in each case that the plaintiff's copyrighted design had been the basis for their own design. ${ }^{54} \mathrm{~A}$ variety of techniques were used to focus judicial attention on the idea-expression distinction. In one case, the Slifkas took a copyrighted design and "cross-bred" it with pictures found in a design form book. Although their product was strikingly identical to the copyrighted article in those features most likely to attract consumer attention-structural characteristics, spatial arrangements, and use of shadings, stippling, colors and color combinations, ${ }^{55}$ they could point to specific pictures in the design form book which served as the basis for their own design. ${ }^{58}$ The court concluded that the Slifkas had "sedulously borrowed each of plaintiff's ideas" but denied relief because "defendant's designs are aesthetic mutations, reflecting major changes and significant alterations that keep clear of plaintiff's expression." 57

Another tactic used successfully by the same defendants was to show that the copyrighted article was appropriated from a public domain work. ${ }^{58}$ The plaintiff had taken an embroidery known as "Schiffli," photographed it, and worked for months to develop an arrangement of colors that would give the flat-surface design a threedimensional effect. The Slifkas bought one of the plaintiff's dresses, softened some of the features including the three-dimensional effect, and used the design for their own product. Although the Second

54 Millworth Converting Corp. v. Slifka, 276 F.2d 443, 444 (2d Cir. 1960); Condotti, Inc. v. Slifka, 223 F. Supp. 412, 415 (S.D.N.Y. 1963); Clarion Textile Corp. v. Slifka, 139 U.S.P.Q. 340 (S.D.N.Y. 1961).

55 Condotti, Inc. v. Slifka, 223 F. Supp. 412, 415 (S.D.N.Y. 1963).

56 Id. at $413-14$.

57 Id. at 415 .

58 Millworth Converting Corp. v. Slifka, 276 F.2d 443, 445 (2d Cir. 1960). Similar strategy has been employed in a number of other cases, Florabelle Flowers, Inc. v. Joseph Markovits, Inc., 296 F. Supp. 304, 307 (S.D.N.Y. 1968); Gardenia Flowers, Inc. v. Joseph Markovits, Inc., 280 F. Supp. 776, 780 (S.D.N.Y. 1968); Ideal Toy Corp. v. Adanta Novelties Corp., 223 F. Supp. 866, 868 (S.D.N.Y. 1963); Elekes v. Bradford Novelty Co., I83 F. Supp. 730, 732-33 (D. Mass. 1960), but not always with the same success, Concord Fabrics, Inc. v. Marcus Bros. Textile Corp., 296 F. Supp. 736, 738 (S.D.N.Y.), rev'd, 409 F.2d 1315 (2d Cir. 1969). 
Circuit found that the plaintiff's design possessed the requisite originality, ${ }^{59}$ it denied relief. Since the design was in the public domain and therefore could be freely copied, the court applied a stricter test of infringement:

We need not determine whether if the basic design had been original with plaintiff, defendant's fabric might not be suffciently imitative to infringe under the test laid down by Judge Hand in Peter Pan. For here, in contrast, the basic design was in the public domain and plaintiff was entitled to relief only if the defendants copied its "expression" . . . 60

Another successful stratagem the Slifkas employed was to change the colors used in the copyrighted design. ${ }^{61}$ Since the normal test for infringement encourages the court to make a judgment based on an overall impression, identity of public domain elements such as color or dress design ${ }^{62}$ may cause the viewer to disregard or minimize differences in detail. This psychological effect, however, works both ways. While identity of color obscures differences in design, disparity in color highlights those differences. Thus, in copying a fabric design consisting of flowers enclosed in staggered rectangles, the Slifkas made some minor alterations ${ }^{63}$ in the design and then changed the color on some but not all ${ }^{64}$ of their fabrics. In denying a request for a preliminary injunction, the court concluded:

The designs are enough alike so that a woman wearing plaintiff's Capri \#751 in brown and green would exclaim "There goes my dress" if she saw a woman wearing Slifka Fabrics No. 9074 in the same color scheme. My belief is, however,

59 Millworth Converting Corp. v. Slifka, 276 F.2d 443, 445 (2d Cir. 1960).

60 Id.; accord, Mattel, Inc. v. S. Rosenberg Co., 296 F. Supp. 1024, 1026 (S.D.N.Y. 1968); Manes Fabrics Co. v. The Acadia Co., 139 U.S.P.Q. 339, 340 (S.D.N.X. 1960).

61 Clarion Textile Corp. v. Slifka, 139 U.S.P.Q. 340 (S.D.N.Y. 1961). For another fabric design case where use of the same tactic may have contributed to denial of a preliminary injunction, see Prestige Fabrics, Inc. v. Universal Mfg. Corp., 304 F. Supp. 903, 905 (S.D.N.Y. 1969).

62 Uncopyrighted dress designs have the same effect as color in obscuring differences in fabric patterns. Therefore, the defendant's chances of success are increased if the court compares the plaintiff's and the defendant's designs as they appear on rolls of cloth before they are made into dresses. See, e.g., Manes Fabric Co. v. Miss Celebrity, Inc., 246 F. Supp. 975 (S.D.N.Y. 1965).

63 The flowers in the plaintiff's designs were impressionistic masses which would overflow the boundaries of the rectangles if not cut by them. The Slifkas made their flowers individual sprays, clearly defined and fitted into the rectangles with unoccupied margins. Clarion Textile Corp. v. Slifka, 139 U.S.P.Q. 340, 341 (S.D.N.Y. 1961).

64 "Among the various color schemes of the fabrics bearing defendant's design there are three which exactly duplicate the three color schemes used by plaintiff on fabrics bearing its design." Id. at 340 . 
that there would be no such exclamation if the Slifka Fabrics No. 9074 were in light green and cerise. ${ }^{65}$

Had the defendants in the toy doll and plastic Santa Claus cases employed tactics similar to the Slifkas', the results might have been different. After examining the copyrighted work, the defendants in all three cases could easily have obtained pictures in the public domain upon which to base their products. ${ }^{66}$ Furthermore, at least on the Beatle dolls, the color of the outer clothing could have been changed on some of the copies without destroying their commercial value. Confronted with this set of facts, the court would have been hard pressed to find infringement.

Nevertheless, there is no guarantee that the issue would have been resolved in this manner. ${ }^{67}$ In attempting to advance human thought and development by protecting expression, some courts have lost sight of the public purpose involved; eliminating appropriation or commercial piracy has become an end in itself. ${ }^{68}$ As a result, even careful copyists may find the idea-expression distinction of no help in an infringement action. Three recent court of appeals cases vividly illustrate this possibility.

In Roth Greeting Cards v. United Card Co., ${ }^{69}$ a case involving copyrights on seven studio greeting cards, the Ninth Circuit was confronted with a defendant who had covered his tracks well. For example, the defendant duplicated the public domain aspects of one of the plaintiff's cards-the uncopyrighted caption was the same; the general mood of the two cards was similar. ${ }^{70}$ However, the art work was quite different-the plaintiff's card had a forlorn boy sitting on a curb weeping; the defendant's portrayed a forlorn and weeping man. ${ }^{71}$

Despite the obvious difference between the two cards, the court reversed judgment for the defendant. The majority concluded that

$65 \mathrm{Id}$. at 341.

66 Of course, even this strategy may involve extra expense for toy doll copiers who use the copyrighted work itself to make a mold for their own product.

67 Even the resourceful Slifkas felt the sting of judicial wrath. Loomskill, Inc. v. Slifka, 330 F.2d 952 (2d Cir. 1964); Cortley Fabrics Co. v. Slifka, 317 F.2d 924 (2d Cir. 1963).

68 [T] he intensity of the search to find what was the plaintiff's original contribution, then to judge whether that was somehow taken by the defendant ... has sometimes driven out other considerations. When thus detached, the law of plagiarism drifts toward excessive protection, with reciprocal excessive constraint, out of proportion to any needed incentive to the producer (the major consideration), and unjustified by any collateral objectives of copyright.

KAPLAN, supra note 7, at 76.

69 Roth Greeting Cards v. United Card Co., 429 F.2d 1106 (9th Cir. 1970).

70 Id. at 1109 .

71 Id. at 1110 . 
"in total concept and feel the cards of United are the same as the copyrighted cards of Roth."72 In reaching a decision which seems to extend copyright protection to an intangible mood, the court appeared influenced by the manner in which the plaintiff and the defendant operated their respective businesses. The plaintiff employed both a writer who developed textual material and an artist who designed the comprehensive layout of the cards. The defendant, on the other hand, employed no writers or artists. Its vice-president admitted that he did the art work himself after obtaining many of his ideas while visiting greeting card shops and gift shows. ${ }^{73}$ In other words, the defendant simply pirated its ideas from other card manufacturers.

The court's apparent reliance on the business morality of the respective litigants represents a significant departure from traditional copyright principles. The amount of time, money, and effort the plaintiff expended in developing his product has no legal significance under the idea-expression distinction. If his original expression has not been appropriated by the defendant, the plaintiff should not be able to buy protection for his ideas no matter how much money he has spent. Likewise, the defendant should not be punished solely because he deliberately capitalized on an idea that the plaintiff made commercially successful. The unprotected status of ideas under copyright law is not confined to those which are commercially valueless. If an idea did not have any worth or value, no one would care whether it were copied. Furthermore, the rationale for leaving ideas unprotected is to expand the field of thought open for development and exploitation; that public purpose can be achieved only if the most valuable ideas are available for appropriation. Therefore, commercial success should be viewed as a reason for encouraging, not restricting, copying of an idea.

The same considerations of business morality, however, also seem to pervade the Fifth Circuit's decision in Tennessee Fabricating Co. $v$. Moultree Manufacturing Co.7. The plaintiff had secured a copyright on a twelve-inch square architectural metal casting unit intended for use in combination or singly for a decorative screen or room divider to "finish up" space. ${ }^{75}$ A filigree pattern of intercepting straight and arc lines covered the surface of the unit. The defendant had come into possession of one of the plaintiff's products on which the copyright notice had been obscured. Using the unit to make a mold, the defendant marketed the identical product. After receiving actual notice of

72 Id.

73 Id. at 1108.

74421 F.2d 279 (5th Cir. 1970).

75 Id. at 280. 
the copyright, it redesigned the unit by "adding four intercepting straight lines in the form of a diamond to the filigree pattern."76

The court held such action insufficient to avoid infringement. Without actually analyzing the features of the two units, the court concentrated on the defendant's conduct. Having emphasized the commercial success of the plaintiff's product, the court concluded that "the defendants displayed a persistent desire to reproduce or capitalize on the unit." 77 As in the Roth case, the right of the defendant to "reproduce or capitalize" on the public domain elements of the plaintiff's product seems to have been ignored.

The extent to which concern for commercial morality can blind a court to the problems raised by the idea-expression distinction was again demonstrated in Concord Fabrics, Inc. v. Marcus Brothers Textile Corp..$^{78}$ The fabric design involved was used primarily on women's handkerchiefs. It consisted of a series of squares, each containing a smaller square which in turn contained a circle. Not only did the Second Circuit minimize differences in the color and design of the defendant's fabric, but it also viewed those changes as evidence of its culpability:

$[W]$ e feel that the very nature of these differences only tends to emphasize the extent to which the defendant has deliberately copied from the plaintiff. ${ }^{79}$

Although the court was not without precedent in viewing the "studied efforts" of the defendant to change the plaintiff's work as proof of infringement, ${ }^{80}$ its reasoning seems clearly incorrect. By protecting expression and not protecting ideas, copyright law encourages authors and artists to make individual variations on common themes. Certainly actions which the law encourages should not be used as evidence of infringement.

Moreover, even if the differences between the plaintiff's and the defendant's products are taken as evidence of copying, the court's inquiry should not end. In order to find infringement, the court still must determine that the defendant has appropriated the plaintiff's protected expression, not merely his ideas. However, the Second Circuit never took this necessary step. Concerned mainly with prevent-

76 Id. at 281.

77 Id. at 282.

78409 F.2d 1315 (2d Cir. 1969).

79 Id. at 1316.

80 See, e.g., Mattel, Inc. v. S. Rosenberg Co., 296 F. Supp. 1024, 1026 (S.D.N.Y. 1968); Hassenfield Bros., Inc. v. Mego Corp., 150 U.S.P.Q. 786, 788 (S.D.N.Y. 1966); Peter Pan Fabrics Inc. v. Candy Frocks, Inc., 187 F. Supp. 334, 336 (S.D.N.Y. 1960); Scarves By Vera, Inc. v. United Merchants \& Mfrs., Inc., 173 F. Supp. 625, 627 (S.D.N.Y. 1959). 
ing commercial piracy, the court brushed aside all differences between the two products as unsubstantial without ever discussing what those differences were. ${ }^{81}$

Despite the court's curt treatment of the issue, an examination of the lower court opinion suggests that the differences between the two products were anything but insignificant. The district court had found that the motifs of the two handkerchiefs were distinguishable in that the defendant's work had approximately 25 daisies which did not appear in the plaintiff's while the latter had twelve geometrical shaped designs which had no counterpart in the defendant's pattern. ${ }^{82}$ More importantly, the district court noted that the basic design of the plaintiff's handkerchief-the series of larger squares-had been common and popular throughout the women's clothing industry for many years-a fact never mentioned by the court of appeals. ${ }^{83}$ Thus, only by concentrating on the defendant's conduct and ignoring the type of detailed examination which the district court conducted could the Second Circuit escape the conclusion that

[a]t worst, what defendant has done here is to use an idea of plaintiff's, to wit, the imposition of a smaller square and a circular design therein within the framework of a large handkerchief design..$^{84}$

The real importance of these three decisions is not that they depart from traditional doctrine, but that they threaten to introduce an amorphous, far-reaching principle into the already unsettled world of substantive copyright law. The factors which support the decisions-the commercial success of the plaintiff's product, the amount of time, money, and effort expended by the plaintiff, the defendant's actual use of the plaintiff's work in making his own product-are many of the constituent elements of the common law doctrine of unfair competition. $^{85}$ Moreover, the prevailing philosophy in all three opinions appears to be identical to that of unfair competition cases: that the primary function of the courts is to prevent the "competitor from reaping the fruits of complainant's efforts, and expenditures, to the partial exclusion of complainant." 86

81409 F.2d 1315, 1316 (2d Cir. 1969).

82296 F. Supp. 736, 738 (S.D.N.Y. 1969).

83 Id.

$84 \mathrm{Id}$.

85 See, e.g., Aetna Bldg. Maintenance Co. v. West, 39 Cal. 2d 198, 246 P.2d 11 (1952); Peerless Oakland Laundry Co. v. Hickman, 205 Cal. App. 2d 556, 23 Cal. Rptr. 105 (1962); Western Electro-Plating Co. v. Henness, 196 Cal. App. 2d 564, 16 Cal. Rptr. 691 (1961); California Intelligence Bureau v. Cunningham, 83 Cal. App. 2d 197, 188 P.2d 303 (1948).

86 International News Serv. v. Associated Press, 248 U.S. 215, 241 (1918). 
The problem with this misappropriation principle is that it has no bounds. Carried to its logical extreme it might completely eliminate all competition, since any time a businessman uses a competitor's idea he is "reaping the fruits" of the latter's efforts and expenditures. Because of these implications, attempts have been made to limit the doctrine. ${ }^{87}$ Only seven years ago, the Supreme Court in Sears, Roebuck \& Co. v. Stiffel Co. ${ }^{88}$ and Compco Corp. v. Day-Brite Lighting, Inc. ${ }^{89}$ appeared to place severe restrictions on the area in which state unfair competition law could operate. However, what may be occurring in the three recent court of appeals decisions is that the misappropriation doctrine is being resurrected phoenix-like from the ashes of Stiffel and Compco and enshrined in substantive copyright law. Such a development would replace the ephemeral idea-expression distinction with a concept of even more uncertain and baffling proportions.

\section{Mazer v. Stein Revisited}

The developments in the seventeen years following Mazer $v$. Stein represent a departure from traditional copyright principles that should be unsatisfying to all but ardent protectionists. Due to the misapplication or non-application of the idea-expression concept, commercial copyrights have been upheld on a plethora of objects which belong in the public domain. Moreover, the introduction of the misappropriation doctrine threatens to destroy the few enclaves of non-protection which still exist. Copyright law, therefore, stands in danger of becoming "a game of chess in which the public can be checkmated."

Some of these problems can be eliminated or at least controlled by a rigorous analysis of each case in terms of the idea-expression distinction. However, one wonders whether it is worth the trouble. The idea-expression distinction has always been an ephemeral concept, a hazy guide to analysis rather than a well-defined standard for decision. In the commercial copyright area, the difficulties of application have been accentuated. The logic of the situation demands not merely the reapplication of a nebulous principle, but a complete reevaluation of the Mazer decision itself.

87 For example, in Cheney Bros. v. Doris Silk Corp., 35 F.2d 279 (2d Cir. 1929), cert. denied, 281 U.S. 728 (1930), Judge Learned Fand tried to confine the International News Service case to its facts. "The difficulties of understanding it otherwise are insuperable." Id. at 280 .

88376 U.S. 225 (1964).

89376 U.S. 234 (1964).

90 Morrissey v. Procter \& Gamble Co., 379 F.2d 675, 679 (Ist Cir. 1967). 
Given the manner in which the Supreme Court formulated the issue in Mazer, it is hard to see how it could have reached a different decision:

This case requires an answer... as to an artist's right to copyright a work of art intended to be reproduced for lamp bases. ${ }^{91}$

The purpose of copyright law is to protect the commercial value of copyrighted works, thereby providing the monetary incentives necessary to encourage the activities of authors and artists. Since the entire copyright system is so commercially oriented, it would seem absurd to deny copyright status to a statuette merely because it was to be put to a commercial use.

However, changing the characterization of the problem yields a different perspective. According to the defendant's petition for certiorari,

Stripped down to its essentials, the question presented is: Can a lamp manufacturer copyright his lamp bases? ${ }^{92}$

Viewed in this manner,,$^{93}$ the wisdom of the Supreme Court's decision is highly questionable. The copyright system has run into problems whenever it has been applied to something other than the type of literary work for which it was originally designed. ${ }^{94}$ Therefore, extending the system to items such as lamp bases which did not even fall within the ordinary conception of a work of art was bound to cause extreme difficulties. Seventeen years of experience has only confirmed the weaknesses inherent in the basic policy of attempting to fit fabric designs, artificial flowers, and plastic Santa Clauses within the mold of standard copyright law.

The sensible solution would be to take the problem of protecting mass-produced, commercial articles entirely out of the copyright system. This action would necessarily involve concurrent restrictions on copyrights covering works of fine art. Otherwise, fabric converters could copyright their fabric designs as paintings, or doll manufacturers register their dolls as sculpture. A more subtle means by which a commercial user could achieve the same end would be secretly to hire another to do the necessary art work under his guidance; this "inde-

91347 U.S. 201, 205 (1954).

92 Id. at 205.

93 The Supreme Court might have had difficulty in accepting the defendant's characterization because the statuettes were not used solely as lamp bases. The plaintiffs also sold them separately as works of art.

04 KAPLAN, supra note 8 , at 85 . 
pendent" artist would then secure a copyright and immediately grant an exclusive license to the manufacturer. In either case, the courts would remain beset with the same perplexing problems which they presently endure.

These difficulties could be overcome by completely eliminating the right of copyright holders to bring infringement actions for unauthorized use of their works in mass-produced, commercial products. However, that solution may conflict with the legitimate interest of artists in protecting the value of their creations as works of fine art. Conceivably, that value could be diminished or destroyed if their works were used in mass-produced, commercial articles.

Fortunately, protecting this legitimate artistic interst can easily be reconciled with the removal of mass-produced, two- and threedimensional objects from the realm of copyright law. For example, owners of copyrights on works of fine art could be allowed to bring regular infringement actions against commercial exploiters of their work, as long as the copyright owner (1) did not use the copyrighted work in his own commercial product; (2) did not license others to use the work in their commercial products; and (3) did not enforce his copyright in such a way as to grant de facto licenses to certain people. Under this approach, the copyright owner would retain all his present powers to protect his work as a work of fine art; he merely would be prevented from profiting from the use of that work in massproduced, commercial products.

While the elimination of commercial copyright problems need not substantially affect the amount of protection afforded works of fine art, the same statement naturally cannot be made concerning the commercial products themselves. They will be completely deprived of copyright protection. Yet such action does not necessarily mean that these products will be left entirely without legal protection. The withdrawal of copyright status might serve as an impetus for special legislation tailored to the particular subject matter involved. Such legislation would, in fact, provide greater security for present commercial copyright owners who must still face the prospect that some courts will engage in a rigorous idea-expression analysis, an analysis usually leading to the conclusion that

there were few similarities that could figure as unexcused limitations of "expression," and those so discrete and of such a dimension as to be nonactionable. ${ }^{95}$

In any event, whether mass-produced, commercial articles remain 
legally protected or unprotected, they should be judged on their own merits. They should not receive protection because of their tenuous connection to a system which was not originally designed for them and remains unequipped to handle them. 